\author{
Evren Hincal ${ }^{1}$, Shorsh Mohammed ${ }^{2}$, Bilgen Kaymakamzade ${ }^{1}$ \\ ${ }^{1}$ Department of Mathematicts, Near East University, TRNC, Turkey \\ ${ }^{2}$ Department of Mathematics, College of Science, University of Sulaymaniyah, Kurdistan Region, Iraq \\ (E-mail: evren.hincal@neu.edu.tr, shorshmohamed6@gmail.com,bilgen.kaymakamzade@neu.edu.tr)
}

\title{
Stability analysis of an eco-epidemiological model consisting of a prey and two competing predators with SI-disease in prey and toxicant
}

\begin{abstract}
In the present paper, we study two eco-epidemiological models. The first one consists of a prey and two competing predators with SI-disease in prey species spreading by contacts between susceptible prey and infected prey. This model assumes linear functional response. The second model is the modification of the first one when the effect of toxicant is taken into account. In this paper, we examine the dynamical behavior of non-survival and free equilibrium points of our proposed model.
\end{abstract}

Keywords: Stability analysis, epidemiological model, prey, predator.

\section{Introduction}

In the nature, no species live alone. There are many hundreds or thousands of species in any given environment, in which two populations interact either by competition or mutualism or prey-predator. In the beginning of twentieth century, a number of attempts were made to predict the evolution and existence of species mathematically. Indeed, the first major attempt in this direction was due to the well known classical Lotka-Volterra model in 1927. Since then many complicated models for two or more interacting species have been proposed according to the Lotka-Volterra model by taking into account the effect of competition, time delay, functional response, etc. (see, e.g., [1,2] and the references therein). On the other hand, over the last few decades, mathematics has been used to understand and predict the spread of diseases, relating important public-health questions to basic transmission parameters. The detailed history of mathematical epidemiology and basics for SIR epidemic models (or Kermack-McKendrick model) can be found in the classical books $[1,3]$. However, recently Haque and Venturino [4] have discussed mathematical models of diseases spreading in symbiotic communities. During the last three decades, there has been growing interest in the study of infectious disease coupled with prey-predator interaction models. In many ecological studies of prey-predator systems with disease, it is reported that the predators take a disproportionately high number of parasite-infected prey. Some studies have even shown that parasites could change the external features or behavior of the prey so that infected preys are more vulnerable to predation (see $[5,6]$ and the references therein). Later on, many authors have proposed and studied ecoepidemiological mathematical models incorporating ratio-dependent functional response, toxicant, external sources of disease, predator switching and infected prey refuge $[1,2,7,8]$.

In the present paper, we formulate two types of eco-epidemiological models, the first one consisting of a prey and two competing predators with SI-disease in prey species. The disease spreads by contact between susceptible prey and infected prey; the proposed model includes linear functional response. The second model is the modification of the first one by taking into account the effect of toxicant.

\section{Model formulation}

In this section, a prey-predator model consisting of a prey and two competing predators with SIdisease in prey species proposed and analyzed. The disease spreads by contact between susceptible prey and infected prey. The proposed model includes linear functional response and is given by 


$$
\begin{array}{r}
\frac{d S}{d T}=r S\left(1-\frac{S}{K}\right)-\left(m+\frac{\lambda I}{1+I}\right) S, \\
\frac{d I}{d T}=\left(m+\frac{\lambda I}{1+I}\right) S-\mu_{1} I Y-\mu_{2} I Z-d_{1} I, \\
\frac{d Y}{d T}=e_{1} I Y-\alpha_{1} Y Z-d_{2} Y, \\
\frac{d Z}{d T}=e_{2} I Z-\alpha_{2} Y Z-d_{3} Z,
\end{array}
$$

where $r, k, m, e_{1}, e_{2}, \alpha_{1}, \alpha_{2}, \mu_{1}, \mu_{2}, d_{1}, d_{2}, d_{3}$ are positive parameters. At time $T \geq 0$ prey population is divided into two classes, namely, susceptible $S(T) \geq 0$ and infected $I(T) \geq 0$ due to the existence of infectious disease, interacting with two competing predators species $Y(T) \geq 0$ and $Z(T) \geq 0$, which describe the population densities of the first and second predator, respectively.

The modified model is given by

$$
\begin{array}{r}
\frac{d S}{d t}=r S\left(1-\frac{S}{K}\right)-\left(m+\frac{\lambda I}{1+I}\right) S-\sigma_{1} W S, \\
\frac{d I}{d t}=\left(m+\frac{\lambda I}{1+I}\right) S-\mu_{1} I Y-\mu_{2} I Z-\sigma_{1} I W-d_{1} I, \\
\frac{d Y}{d t}=e_{1} I Y-\alpha_{1} Y Z-d_{2} Y, \\
\frac{d Z}{d t}=e_{2} I Z-\alpha_{2} Y Z-d_{3} Z, \\
\frac{d U}{d t}=\pi-\sigma_{3} U(S+I)-d_{4} U, \\
\frac{d W}{d t}=\sigma_{3} U(S+I)-d_{5} W,
\end{array}
$$

where $W(t)$ is the toxicant concentration in the prey population at time $t$ and $U(t)$ is the environment concentration of toxicant at time $t$. Here, the new parameters can be described as follows: $\pi$ is the exogenous inputrate of the toxicant in the environment; $d_{4}$ is the natural depletion rate of the environmental toxicant; $d_{5}$ is the natural washout of the toxicant from organism; $\sigma_{1}$ and $\sigma_{2}$ are the rates at which susceptible and infected prey are decreeing due to the toxicant and $\sigma_{3}$ is the uptake rate of toxicant by organism.

The existence of the equilibrium points of system (2) can be guaranteed easily by using basic routine techniques and following Routh-Hurwitz criteria. It turns out that we have the trivial equilibrium point $J\left(0,0,0,0, \frac{\pi}{d_{4}}, 0\right)$, which always exists, and the predators free equilibrium point $\left(S_{0}, I_{0}, 0,0, U_{0}, W_{0}\right)$. 


\section{Boundedness}

The following theorem ensures the boundedness of the system (2).

Theorem 1. All solutions of the system (2) that start in $R_{+}^{6}$ are uniformly bounded, that is

$$
\operatorname{Sup}(S+I+Y+Z+W+U) \geq \frac{\pi+(r+d) K}{d}
$$

Proof. The proof of theorem is similar to the case where the extra conditions are not included, it is omitted here as it is easy.

\section{Analysis of non survival equilibrium point}

The variation matrix of the non survival equilibrium point is

$$
J\left(0,0,0,0, \frac{\pi}{d_{4}}, 0\right)=\left(b_{i j}\right)_{6 \times 6},
$$

where $b_{11}=r-m, b_{21}=m, b_{22}=-d_{1}, b_{33}=-d_{2}, b_{44}=-d_{3}, b_{55}=-d_{4}, b_{66}=-d_{5}$ and all other entries are zeros. So the eigenvalues of $J\left(0,0,0,0, \frac{\pi}{d_{4}}, 0\right)$ are $r-m,-d_{1},-d_{2},-d_{3},-d_{4}$ and $-d_{5}$. $\left(0,0,0,0, \frac{\pi}{d_{4}}, 0\right)$ is locally asymptotically stable if and only if $r<m$.

\section{Analysis of the free predator equilibrium point}

The free predator equilibrium point is $\left(S_{0}, I_{0}, 0,0, U_{0}, W_{0}\right)$, where $S_{0}, I_{0}, U_{0}$ and $W_{0}$ are positive solutions of the following system

$$
\begin{array}{r}
r\left(1-\frac{S}{K}\right)-\left(m+\frac{\lambda I}{1+I}\right)-\sigma_{1} W=0 \\
\left(m+\frac{\lambda I}{1+I}\right) S-\mu_{1} I Y-\mu_{2} I Z-\sigma_{1} I W-d_{1} I=0, \\
\pi=\sigma_{3} U(S+I)+d_{4} U, \\
\sigma_{3} U(S+I)=d_{5} W .
\end{array}
$$

Theorem 2. The free predator equilibrium point of the system (2) is locally stable if the following conditions hold

$$
\begin{array}{r}
\frac{\lambda S_{0}}{\left(1+I_{0}\right)^{2}}<\sigma_{1} W_{0}+d_{1}, \\
I_{0}<\min \left\{\frac{d_{2}}{e_{1}} \frac{d_{3}}{e_{2}}\right\}, \\
\frac{r}{K}<\frac{\lambda}{\left(1+I_{0}\right)^{2}}+\sigma_{1}, \\
\left|\frac{\lambda S_{0}}{\left(1+I_{0}\right)^{2}}-\sigma_{1} W_{0}-d_{1}\right|<m+\frac{\lambda I_{0}}{1+I_{0}}+\mu_{1} I_{0}+\mu_{2} I_{0}+\sigma_{2} I_{0}, \\
\max \left\{d_{4}, d_{5}\right\}<2 \sigma_{3} U_{0} .
\end{array}
$$

Proof. Using Gerschgorin Theorem, one can easily prove the theorem. 


\section{Permanence of the population}

In this section we give criteria for the persistence of the population in the system as shown in the following theorem.

Theorem 3. If the following conditions

(i) $\left(m+\theta \lambda+\sigma_{1} \theta\right) \leq 1$,

(ii) $\max \left\{\mu_{1}, \mu_{2}, \sigma_{1}\right\} \leq 1$,

(iii) $\max \left\{\frac{\alpha_{1} \theta+d_{2}}{e_{1}}, \frac{\alpha_{2} \theta+d_{3}}{e_{2}}\right\}<\frac{m \beta}{\left(d_{1}+\theta\right)}$

hold, then the population in the system (2) is persistent.

Proof. From the first equation of the system (2) and using (11), we obtain

$$
\frac{d S}{d t} \geq r S\left(1-\frac{S}{K}\right)-(m+\lambda \theta) S-\sigma_{1} \theta S=r S\left(1-\left(m+\theta \lambda+\sigma_{1} \theta\right)-\frac{S}{K}\right),
$$

where $\theta=\frac{\pi+(r+d) K}{d}$. It gives us

$$
\lim _{t \rightarrow \infty} \inf (S(t)) \geq\left(1-\left(m+\theta \lambda+\sigma_{1} \theta\right)\right) K=\beta .
$$

Due to condition (i) we have

$$
\lim _{t \rightarrow \infty} \inf (S(t))>0
$$

Using (12) and condition (ii), we get

$$
\frac{d I}{d t} \geq m \beta-\left(d_{1}+\theta\right) I
$$

that is

$$
\lim _{t \rightarrow \infty} \inf (I(t)) \geq \frac{m \beta}{\left(d_{1}+\theta\right)}>0
$$

By using (13) and condition (iii), we get

$$
\frac{d Y}{d t} \geq\left(e_{1} \frac{m \beta}{\left(d_{1}+\theta\right)}-\alpha_{1} \theta-d_{2}\right) Y
$$

so that

$$
\lim _{t \rightarrow \infty} \inf (Y(t)) \geq Y_{0}>0
$$

and

$$
\frac{d Z}{d t} \geq\left(e_{2} \frac{m \beta}{\left(d_{1}+\theta\right)}-\alpha_{2} \theta-d_{3}\right) Z
$$

hence

$$
\lim _{t \rightarrow \infty} \inf (Z(t)) \geq Z_{0}>0
$$

where $Y_{0}$ and $Z_{0}$ are initial values.

\section{Numerical simulations}

With the following parameter values

$$
\begin{array}{r}
r=0.999, K=50, m=\mu_{1}=\mu_{2}=\lambda=\sigma_{3}=1, \\
\sigma_{1}=d_{1}=d_{2}=d_{3}=0.5, \sigma_{2}=0.6, e_{1}=e_{2}=0.9, \\
\alpha_{1}=2, \alpha_{2}=1.9, d_{4}=d_{5}=0.1, \pi=100
\end{array}
$$

the system approaches the non survival equilibrium point as shown in Figure 1.

But if we neglect the affect of the toxicant then with the same parameter values (14) the system approaches the predator free equilibrium point $(0.0509,0.1133,0,0)$. That is the prey population will survive as shown in Figure 2. 

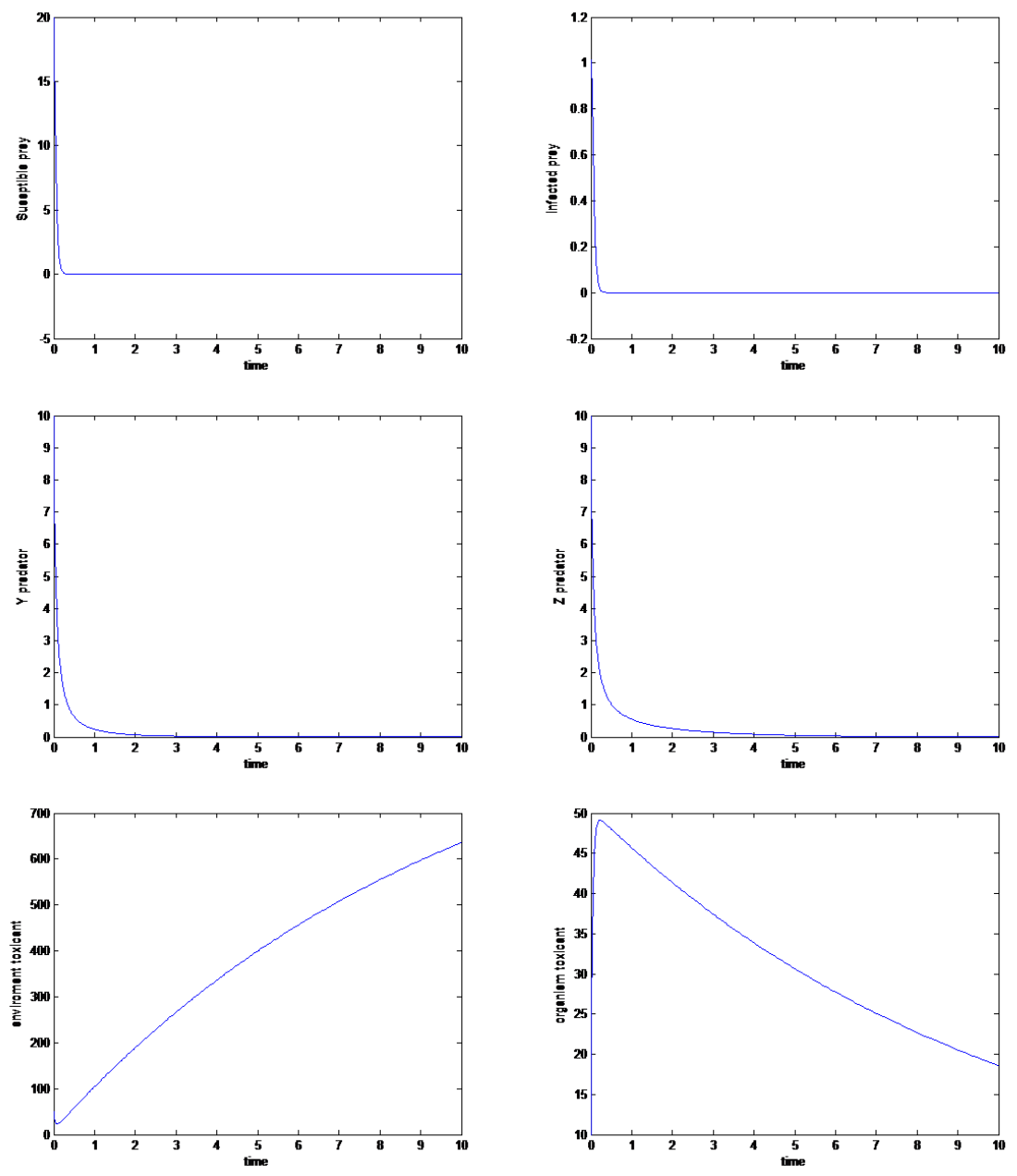

Figure 1.
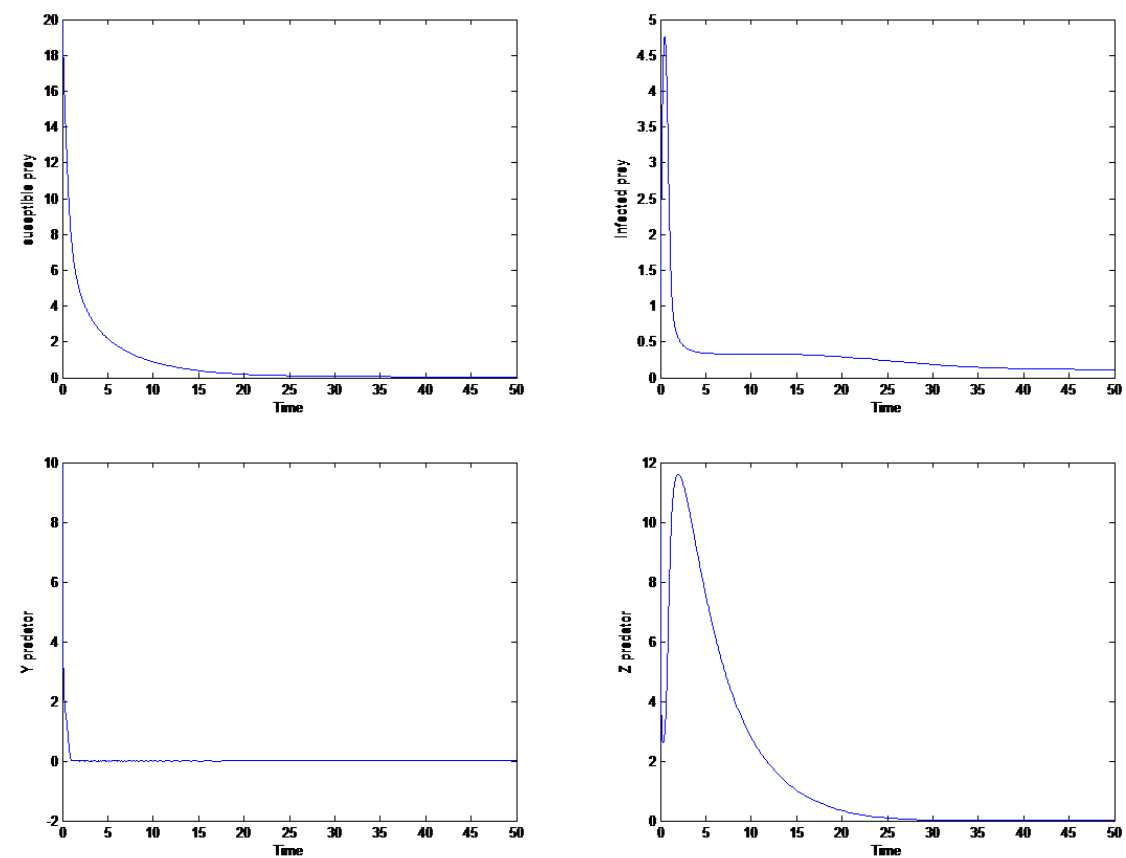

Figure 2. 
In this paper, we study the effect of toxicant on dynamical behavior of proposed model (1). We give the sufficient conditions for permanence of the system and local asymptotic stability of non survival equilibrium point and predator free equilibrium point. We have discovered that decreasing the intrinsic grow rate of the susceptible prey below a contact rate value, as shown in (14), the system (2) approaches a locally asymptotically stable non survival point. However, if we neglect the effect of the toxicant, then for the same set of parameter values (14) system approaches the predator free equilibrium point $(0.0509,0.1133,0,0)$. That is the prey population will survive.

\title{
References
}

1 Freedman, H. Persistence in models of three interacting predator-prey populations / H. Freedman, P. Waltman // Mathematical Biosciences - 1984. - 68. - P. 213-231.

2 Gakkhar, S. Chaos in three species ratio dependent food chain / S. Gakkhar, R.K. Naji // Chaos, Solitions and Fractals - 2002. - 14. - P. 771-778.

3 Anderson, R.M. May, R.M. Infectious Diseases of Humans: Dynamics and Control / Oxford University Press, Oxford, 1998.

4 Bailey, N.T.J. The mathematical theory of infectious diseases/ Griffin, London, 1975.

5 Anderson, R.M. The invasion, persistence and spread of infections disease within animal and plant communities / R.M. Anderson, R.M. May // Philos. Trans. R. Soc. Lond. B Biol Sci 1986. - 314, - No.1167. - P. 533-570.

6 Hadeler K.P. (1989). Predator-prey populations with parasitic infection / K.P. Hadeler, H.I. Freedman // Journal of mathematical Biology - 1989. - 27. - No.6. - P. 609-631.

7 Greenhalgh, D. A predator prey model with disease in the prey species only / D. Greenhalgh, M. Haque // Mathematical Methods in the Applied Sciences - 2007. - 30. - P. 911-929.

8 Haque, M. The role of transmissible diseases in the Holling Tanner predator prey model M. Haque, E. Venturino // Theoretical Population Biology - 2006. - 70. - P. 273-288.

\author{
Э. Хинжал, Ш. Мохаммед, Б. Каймакамзаде
}

\section{Токсиканттан және тарайтын SI ауруы бар екі бәсекелес жыртқыштардан және құрбаннан тұратын экоэпидемиологиялық моделдің тұрақтылығын талдау}

\begin{abstract}
Мақалада екі экоэпидемиологиялық модель зерттелген. Біріншісі сезімтал құрбан мен жұқтырған құрбанның байланысы арқылы таралатын, SI ауруы түрін шығаратын екі бәсекелес жыртқыштан тұрады. Бұл модель сызықты функционалды болжайды. Екінші модель токсиканттың әсерін есептегенде, біріншінің модификациясы болып табылады. Авторлар ұсынылған модель бойынша тіршілік етпейтін және еркін тепе-теңдік нүктелерінің динамикалык тәртібін қарастырған.
\end{abstract}

Kiлm сөздер: орнықтылық талдауы, эпидемиологиялық моделі, олжа, жыртқыш. 
Э. Хинжал, Ш. Мохаммед, Б. Каймакамзаде

\section{Анализ устойчивости экоэпидемиологической модели, состоящей из жертвы и двух конкурирующих хищников с SI-болезнью в добыче и токсиканте}

В статье исследованы две экоэпидемиологические модели. Первая состоит из добычи и двух конкурирующих хищников с SI-болезнью у видов добычи, распространяющихся путем контактов между восприимчивой жертвой и инфицированной жертвой. Эта модель предполагает линейный функциональный отклик. Вторая модель является модификацией первой, когда учитывается влияние токсиканта. Авторами рассмотрено динамическое поведение точек невыживания и свободного равновесия предложенной ими модели.

Ключевые слова: анализ устойчивости, эпидемиологическая модель, добыча, хищник.

\section{References}

1 Freedman, H. \& Waltman, P. (1984). Persistence in models of three interacting predator-prey populations. Mathematical Biosciences, 68, 213-231.

2 Gakkhar, S. \& Naji, R.K. (2002). Chaos in three species ratio dependent food chain. Chaos, Solitions and Fractals, 14, 771-778.

3 Anderson, R.M. \& May, R.M. (1998). Infectious Diseases of Humans: Dynamics and Control. Oxford University Press, Oxford.

4 Bailey, N.T.J. (1975). The Mathematical Ttheory of Infectious Diseases. Griffin, London.

5 Anderson, R.M. \& May, R.M. (1986). The invasion, persistence and spread of infections disease within animal and plant communities. Philos. Trans. R. Soc. Lond. B Biol Sci, 314, 1167, 533570 .

6 Hadeler, K.P. \& Freedman, H.I. (1989). Predator-prey populations with parasitic infection. Journal of mathematical Biology, 27, 6, 609-631.

7 Greenhalgh, D. \& Haque, M. (2007). A predator prey model with disease in the prey species only. Mathematical Methods in the Applied Sciences, 30, 911-929.

8 Haque, M. \& Venturino, E. (2006). The role of transmissible diseases in the Holling Tanner predator prey model. Theoretical Population Biology, 70, 273-288. 